\title{
ECG of the "Newborn" Mouse (Mus Domesticus) with Specific Reference to Comparative AV Transmission
}

\author{
L. HENK VAN DeR TWEEL, Ph.D., JAN STRACKEE, Ph.D., \\ ARNOLD A. STOKHOF, V.D., Ph.D., ${ }^{*}$ CLAES WASSENAAR, M.D., Ph.D., $\dagger$ \\ and FRITS L. MEIJLER, M.D., PH.D. $\dagger$
}

From the Laboratory of Medical Physics, the University of Amsterdam, Amsterdam, the *Dept. of Clinical Sciences of Companion Animals, Faculty of Veterinary Medicine, Utrecht University, Utrecht, and the †InterUniversity Cardiology Institute (ICIN) of The Netherlands, Amsterdam, The Netherlands

\begin{abstract}
Comparative AV Transmission. Introduction: The objective of this study was to record the ECG of the smallest living mammal to extend the domain of data for comparative AV nodal electrophysiologic purposes. These data are needed to establish the relationship between the PR interval and heart size in mammalian species of all sizes.

Methods and Results: In recently born mice (age 1.5 to 8 weeks) weighing between 2.5 and $10 \mathrm{~g}$ and with estimated heart weights between 15 and $60 \mathrm{mg}$, ECGs, using bipolar limb leads, were recorded during general anesthesia. The PR interval, representing AV transmission time was about $\mathbf{4 0} \mathbf{~ m s e c}$, which is quite long for hearts of this size. On the basis of detailed analysis of the data, we postulate the presence of a fixed delay or discontinuous propagation in the AV node not only in newborn mice, but in mammals of all sizes.
\end{abstract}

Conclusion: AV transmission times obtained in mammals (including humans) cannot be explained on the basis of generally accepted, classic AV conduction theories. The acceptance of the presence of a fixed delay in the AV node may ultimately be of value to better understand $\mathrm{AV}$ node function during sinus rhythm and supraventricular arrhythmias. (J Cardiovasc Electrophysiol, Vol. 10, pp. 168-173, February 1999)

$P R$ interval, mouse, comparative AV transmission

\section{Introduction}

Mammalian comparative electrocardiology may help to better understand certain electrocardiography findings in humans in health and disease. This was the main incentive for King et al. ${ }^{1}$ to study the ECG of whales. In 1992, our group ${ }^{2}$ was successful in recording, for the first time, a credible ECG of a humpback whale. As early as

Dr. van der Tweel passed away in May 1997. We dedicate this paper to him.

This study was financially supported by the Whale ECG Foundation, Utrecht, the Netherlands, chaired by his Royal Highness Prince Bernhard of the Netherlands and the Wijnand M. Pon Foundation, Leusden, The Netherlands.

Address for correspondence: Frits L. Meijler, M.D., 20/G Stadhouderskade, 1054 ES Amsterdam, The Netherlands. Fax: 31-20689-1167; E-mail: denham@euronet.nl

Manuscript received 17 September 1998; Accepted for publication 30 October 1998.
1913, Waller ${ }^{3}$ drew attention to the correlation between the size of an animal and its AV transmission time (PR interval) as recorded on the ECG. In 1927, Clark ${ }^{4}$ published a monograph in which he asserted that "the PR interval varies so little in different animals." Further studies ${ }^{5-8}$ of AV transmission times in mammals extended Waller's ${ }^{3}$ and Clark's ${ }^{4}$ findings.

There is, however, still no unifying concept or theory to explain the relation between AV transmission time and hearts of different sizes in mammals. Linear regression of the PR interval on heart length (calculated as the cube root of heart weight) of different mammalian species (including humans), or within one species of different age or race, gives a satisfactory description of the relation between these two measures. However, a striking property of these regression lines is that after extrapolation to heart length 0 , they always seem to intersect the time axis be- 
tween 30 and $100 \mathrm{msec}$. Since heart weight is closely related to body weight $(0.6 \%)^{9,10}$ heart weight can be accurately derived from body weight. It is of interest to note that over a considerable range of heart weights, the PR interval varies with heart length. However, in animals larger than a horse and smaller than a rabbit, the PR interval remains constant. In elephants and whales, it levels off at a value of about 400 msec, ${ }^{11,12}$ even though a whale may weigh 100 times as much as a horse (Fig. 1), and, in small mammals, it remains constant at a value of about 40 to $50 \mathrm{msec}$.

This is all difficult to explain on the basis of classic AV conduction theories, assuming a more or less steady, slow, and continuous propagation of the impulse through the mammalian AV system. ${ }^{13-15}$ Given the rather uniform form, size, and electrophysiologic properties of AV nodal cells in mammals, ${ }^{16}$ one would indeed expect a proportional increase in the PR interval, from 0 to far over 1 second, over the full range of heart dimensions from the smallest to the largest mammal. We took into consideration as many data on
PR interval versus heart size in mammals as could be found in literature, as well as the numerous data recorded previously by our own group. $^{2,5-8,11}$. In this paper, we extend the range of data with those of the smallest possible and readily available mammal, the newborn mouse (mus domesticus), and consider the consequences of the outcome for the understanding of transmission in the AV node.

\section{Methods}

\section{ECG Recording}

Fifty-five mice with an age range from 1.5 to 8 weeks weighing 2.5 to $10 \mathrm{~g}$ (average weight: $9.00 \mathrm{~g} ; \mathrm{SD}: 1.85 \mathrm{~g}$ ) were anesthetized with a mixture of nitrous oxide, isoflurane, and oxygen by mask. ECGs using bipolar extremity leads were recorded during 10 seconds with the aid of 26G hypodermic needles in the front and hind limbs of the animals in dorsal recumbency. To

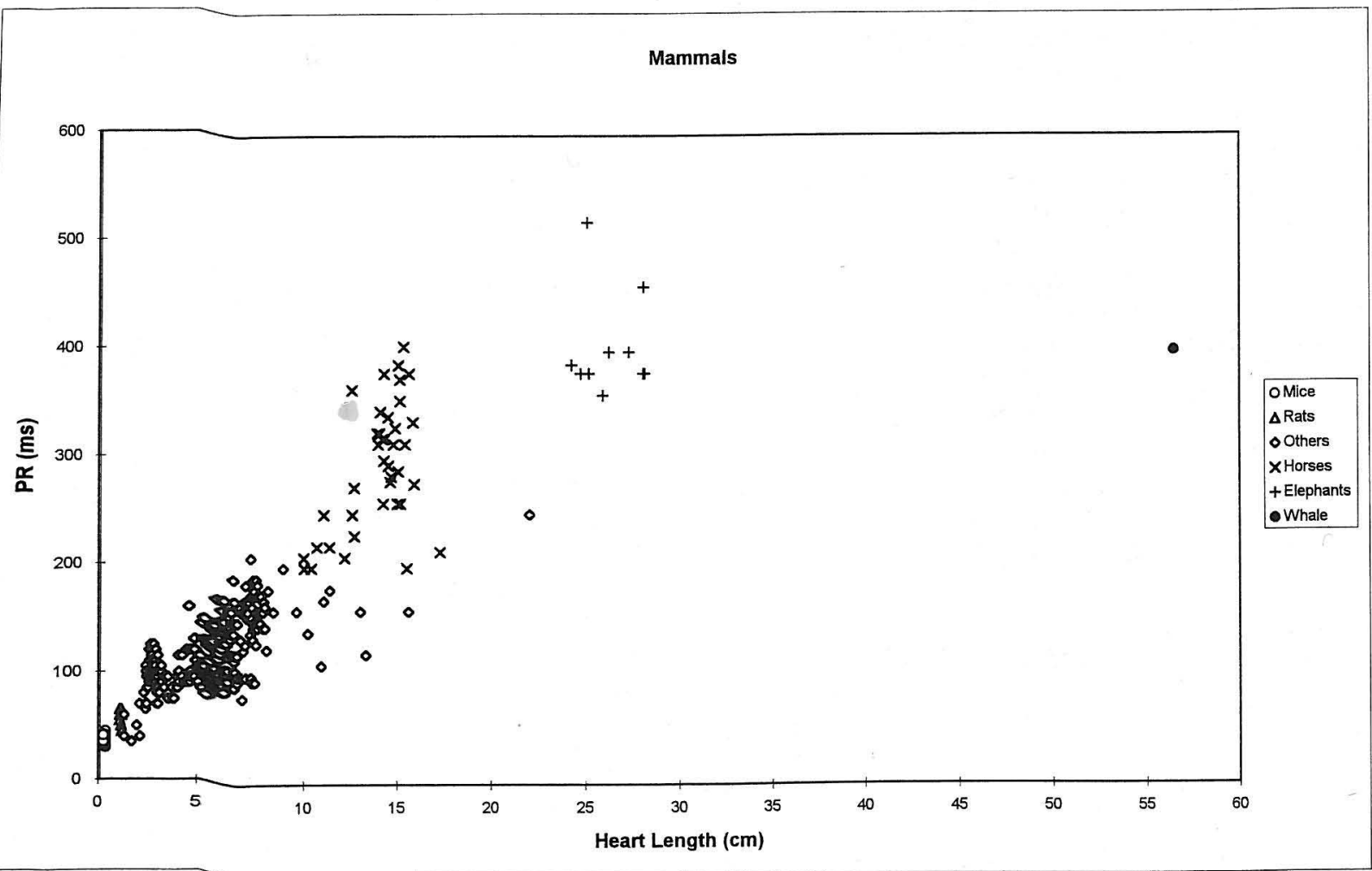

Figure 1. Relation of the PR interval versus heart length in mammals ranging from mice to whales. Horses, elephants, and whales have approximately the same PR interval. At heart length 0 , the PR interval has a value of approximately 50 msec. "Others" comprise humans of all ages and numerous mammalian species. 
prevent hypothermia, the mice were positioned on a heated pad, kept at $40^{\circ} \mathrm{C}$.

\section{Results}

\section{ECG Data}

The ECG of our smallest mouse weighing $2.5 \mathrm{~g}$ (Fig. 2) is representative of all ECGs of all mice. Taking into account the $0.6 \%$ rule of heart weight versus body weight, ${ }^{10}$ the heart of this particular mouse had an estimated weight of 15 $\mathrm{mg}$, so that the overall length of the heart would have been slightly over $2.5 \mathrm{~mm}$ and the length of the AV conduction system even less. The PR interval in this case, however, is just over 40 msec; the average PR interval of all mice was $37.3 \mathrm{msec}$ with a standard deviation of $3.7 \mathrm{msec}$. The average heart rate was 468 beats/min (SD: 28).

A relevant finding was that the PR interval in mice is not affected by age, weight (heart size), or heart rate. We also do not take into consider- ation a significant effect of the general anesthesia on the PR interval as this is never observed in other animals under the same circumstances. Moreover, our mice ECG data agree quite well with those found by others. ${ }^{17}$ Figure 3 shows the relationship between heart size and the PR interval of all mammals on a logarithmic scale. From these data we can further assume that the length of the AV conduction system in mice hardly affects the PR interval. For all practical purposes, we estimate the length of the atria as one third of the total heart length, thus approximately $1 \mathrm{~mm}$.

\section{Data Analysis}

The PR interval consists of three components: (1) SA: the time needed for the impulse to travel from the sinoatrial node to the AV node (internodal transmission); (2) AV: the time it takes for the impulse to move across the AV node (intranodal transmission); and (3) HP: the time the impulse takes to travel along the His-Purkinje system. So, $\mathrm{PR}=\mathrm{SA}+\mathrm{AV}+\mathrm{HP}$.

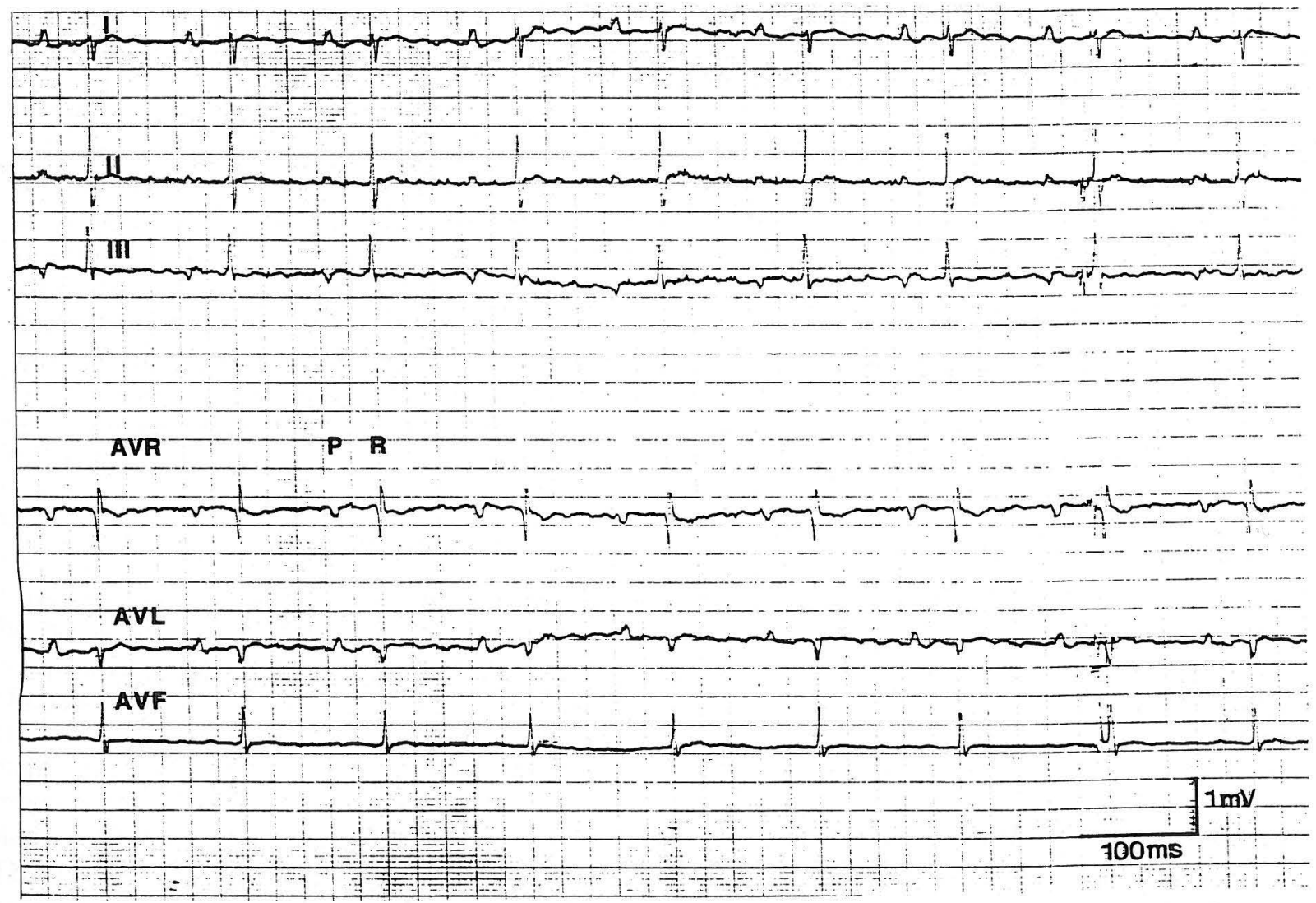

Figure 2. ECG of a newborn mouse weighing $2.5 \mathrm{~g}$. The PR interval is close to $40 \mathrm{msec}$, which is extremely long for a heart of this size. 


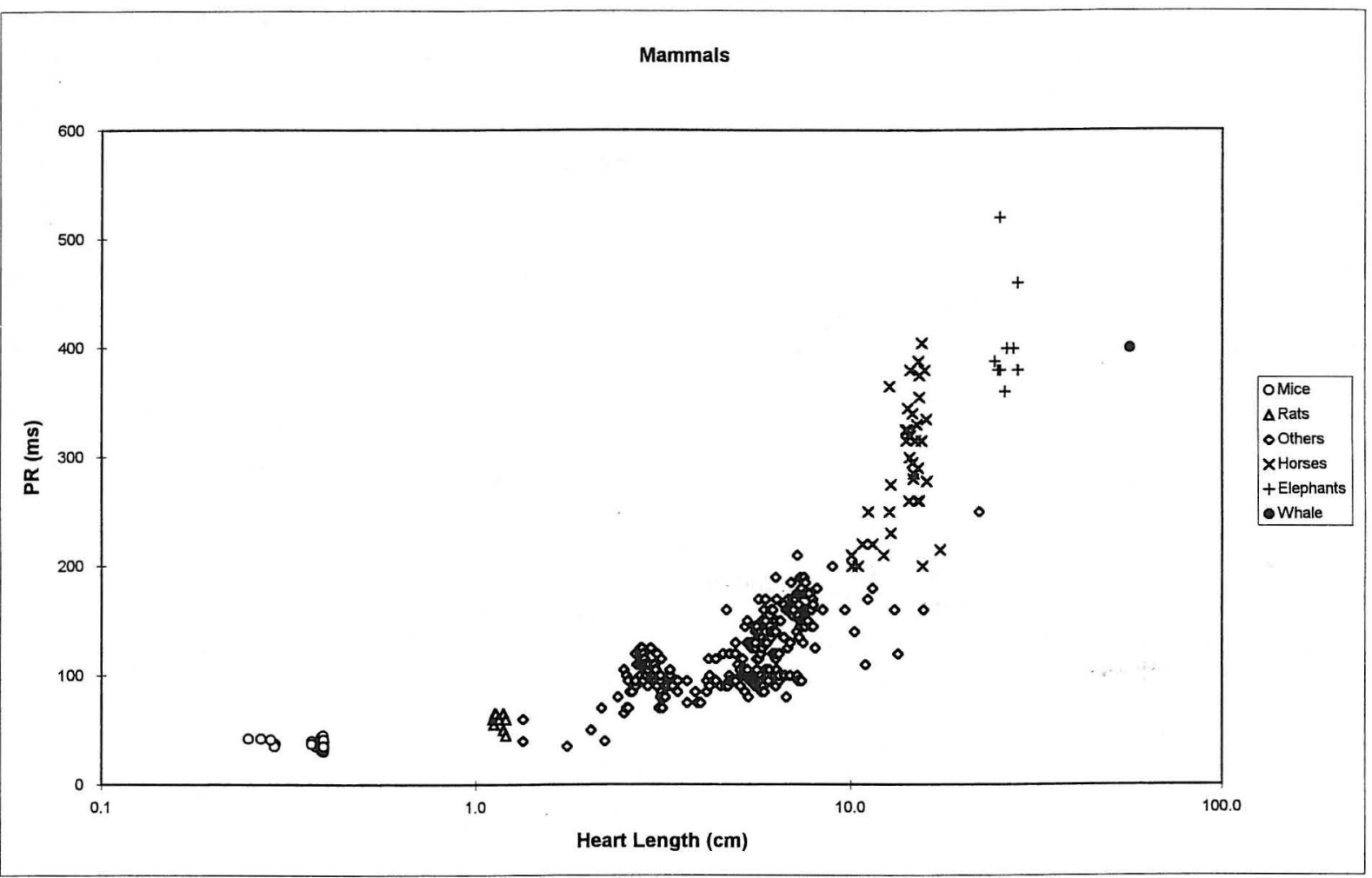

Figure 3. Relation of the $P R$ interval versus heart length presented on a logarithmic scale. It can be seen that all newborn mice, irrespective of their sizes, have approximately the same PR interval, and that in the rat (weighing $300 \mathrm{~g}$ ), it is hardly any longer. The $S$ shape of the curve should be noted.

With respect to SA, it may not be justified to equate internodal conduction as being the same as atrial myocardial conduction, ${ }^{18}$ which in dogs and humans is in the order of $50 \mathrm{~cm} / \mathrm{sec} .{ }^{19}$ Schaper and Stammler $^{20}$ did a morphometric study of mammalian myocardium, including mice. They did not find significant differences between the diameter of myocardial cells in the species they studied. Internodal conduction would be rather faster, as opposed to slower, than $50 \mathrm{~cm} / \mathrm{sec}$, so over a distance of $1 \mathrm{~mm} \mathrm{SA}$ can hardly have been longer than $2 \mathrm{msec}$; but to be on the safe side, we take for SA $5 \mathrm{msec}$. At an average PR interval in the mouse of $40 \mathrm{msec}$, there is at least $35 \mathrm{msec}$ left for AV + HP. The length of the AV node may be neglected, which allows for a length of $2 \mathrm{~mm}$ for HP. Truex and Smythe $^{21}$ did not specifically mention the mouse in their study on comparative morphology of His-Purkinje fibers. In the bat, rat, guinea pig, and rabbit the "presumptive conduction fibers" of the ventricles demonstrate little or no differentiation and are difficult to distinguish from ventricular muscular fibers. A myocardial con- duction velocity of approximately $50 \mathrm{~cm} / \mathrm{sec}$ would take $10 \mathrm{msec}$ at most for the impulse to travel the distance of $2 \mathrm{~mm}$ from the AV node to and through the ventricular myocardium. This leaves us with a minimum time of 25 to $30 \mathrm{msec}$ for intranodal transmission (AV). A transmission time of $25 \mathrm{msec}$ over a distance approaching 0 implies an unrealistically slow conduction or a fixed delay inside the AV node.

\section{Discussion}

Knowledge of the AV node function is essential for diagnosis and treatment of supraventricular arrhythmias in man. ${ }^{1,22,23}$ Despite a vast body of knowledge, many facets of AV nodal transmission and its protection against atrial tachycardias remain an enigma. ${ }^{15,24}$ For instance, simple or rather simplistic decremental conduction in the AV node cannot satisfactorily explain rate and characteristics of ventricular rhythm in atrial fibrillation. ${ }^{24,25}$ Also, taking into consideration the widely accepted decremental conduction theory, ${ }^{15}$ the complicated relation- 
ship between the PR interval and heart size cannot be truly understood. This is exemplified by recent measurements of premature born infants, weighing between 500 and $1,000 \mathrm{~g}$ and a heart weight between 3 and $6 \mathrm{~g}$, which showed an average PR interval of $90 \mathrm{msec}^{26}$

The overall architecture of all mammalian hearts is essentially similar. This similarity also applies to the morphology of the AV node among smaller and larger mammals ${ }^{16,27}$ and to the myocardium, which is composed of individual fibers that tend to be uniform in diameter, approximately 10 to $15 \mu .{ }^{16}$ Conduction velocity in living fibers depends largely on cell (fiber) diameter. $^{28,29}$ Given the more or less uniform diameter of myocardial cells throughout the whole mammalian kingdom, we may infer fairly constant conduction velocities in the myocardial fibers of all mammals. Indeed, the ventricles of a mouse are so small that functioning Purkinje fibers are hardly needed. ${ }^{16}$ But even if some Purkinje fibers existed ${ }^{30}$ and, therefore, conduction velocity differences between small and large mammals were present, this could hardly affect conduction times in hearts of the size of a few millimeters.

The relatively long and constant duration of AV transmission time in small mammals and the relatively short and constant PR interval in large mammals result in the classic and unexplained S-shape curve ${ }^{31}$ shown in Figure 3. It must have an evolutionary basis and be responsible for an optimal efficacy of the hemodynamic function of the heart. ${ }^{32}$ The S-shaped relationship between the PR interval and heart size may be due to discontinuous propagation in the AV node. Discontinuous propagation, if operative during sinus rhythm in intact mammalian hearts, ${ }^{24,33}$ could be responsible for the apparent fixed delay in the AV node, and would affect AV transmission in small hearts more than in large ones. The concept of a fixed delay is the result of extrapolation of the PR interval to heart weight (size) 0 . This concept is confirmed by the observation of long PR intervals in newborn mice weighing 2.5 to $10 \mathrm{~g}$. The fixed delay could be rather constant in mammals of all sizes, and should be subtracted from the total PR interval to calculate transmission velocities in the different parts of the heart. The clinical consequences of these findings are as yet unclear.

The true riddle is why a rat of $300 \mathrm{~g}$ would have the same PR interval as a newborn mouse of
$5 \mathrm{~g}$, and why a whale of $30,000 \mathrm{~kg}$ would have the same PR interval as a horse of $500 \mathrm{~kg}$.

\section{Conclusion}

AV transmission time is the result of at least two mechanisms: (1) a fixed delay of an incoming atrial impulse or an episode of marked slowing of conduction (discontinuous transmission) in the AV node, a mechanism especially important in small mammals; and (2) propagation of the impulse along the cells of the AV node and HP system. The contribution of this mechanism gains importance when hearts get bigger.

There is a striking S-shaped relationship between the PR interval and heart size, which deserves further attention.

Acknowledgments: The authors wish to thank Drs. Charles Fisch and José Jalife for their critical comments and for keeping us straight on the path of AV transmission, and Mr. Earl E. Bakken for his continuing support of the Whale ECG Foundation.

\section{References}

1. King RL, Jenks JL, White PD: The electrocardiogram of a Beluga whale. Circulation 1953;8:393-397.

2. Meijler FL, Wittkampf FHM, Brennen KR, et al: Electrocardiogram of the humpback whale (megaptera ovaeangliae), with specific reference to atrioventricular transmission and ventricular excitation. J Am Coll Cardiol 1992;20:475-479.

3. Waller AD: Cardiology and cardiopathology. Br Med J 1913;2:375-376.

4. Clark AJ: Comparative Physiology of the Heart. Cambridge University Press, Cambridge, 1927, pp. 49-51.

5. Lombard EA: Electrocardiograms of small mammals. Am J Physiol 1952;171:189-193.

6. Zuckermann R: Grundriss und Atlas der Elektrokardiographie. VEB Georg Thieme, Leipzig, 1955, pp. 626-646.

7. Grauwiler J: Beobachtungen am Elektrokardiogramm von nicht-domestizierten Saugetiere. Schweiz Archiv Tierheilkd 1961;103:397-417.

8. Meijler FL, Janse MJ: Morphology and electrophysiology of the mammalian atrioventricular node. Physiol Rev 1988;68:608-647.

9. Schmidt-Nielsen K. Scaling: Why Is Animal Size So Important? Cambridge University Press, Cambridge, 1984, pp. 126-130.

10. Prothero J: Heart weight as a function of body weight in mammals. Growth 1979;43:139-150.

11. Wassenaar C: Comparative Electrocardiography in Mammals. Thesis, University of Utrecht, The Netherlands, 1993.

12. Meijler FL: Atrioventricular conduction versus heart 
size from mouse to whale. J Am Coll Cardiol 1985;5: 363-365.

13. Hoffman BF, Cranefield PF: Electrophysiology of the Heart. McGraw-Hill, New York, 1960, pp. 156-162.

14. Paes de Carvalho A, de Almeida DF: Spread of activity through the atrioventricular node. Circ Res 1960;8:801809.

15. Watanabe $\mathbf{Y}$, Watanabe $\mathbf{M}$ : Impulse formation and conduction of excitation in the atrioventricular node. J Cardiovasc Electrophysiol 1994;5:517-531.

16. Sommer JR, Johnson EA: Ultrastructure of cardiac muscle. In Berne RM, Sperelakis N, Geiger SR, eds: Handbook of Physiology. The Cardiovascular System. I. The Heart. American Physiological Society, Bethesda, 1979, pp. 113-186.

17. Goldbarg AN, Hellerstein HK, Bruell JH, et al: Electrocardiogram of the normal mouse. Mus musculus: General considerations and genetic aspects. Cardiovasc Res 1968;2:93-99.

18. James TN: Connecting pathways between the sinus node and $\mathrm{A}-\mathrm{V}$ node and between the right and left atrium in the human heart. Am Heart J 1963;66:498508.

19. Durrer D, Janse MJ, Lie KI, et al: Human cardiac electrophysiology. In Dickinson CJ, Marks J, eds: Developments in Cardiovascular Medicine. MTP Press, Lancaster, 1978, pp. 53-75.

20. Schaper J, Stammler G: Comparative morphometry of mammalian myocardium. Proc R Neth Acad Sci 1990; 93:501-505.

21. Truex RC, Smythe MQ: Comparative morphology of the cardiac conduction tissue in animals. Ann N Y Acad Sci 1965;127:19-23.

22. Scherf D, Schott A: Extrasystoles and Allied Arrhythmias. Second Edition. William Heinemann Medical Books, Ltd, Chicago, 1973 pp. 441-487.

23. Langendorf R: Concealed A-V conduction: The effect of blocked impulses on the formation and conduction of subsequent impulses. Am Heart J 1948;35:542-552.

24. Meijler FL, Jalife J, Beaumont J, et al: AV nodal function during atrial fibrillation: The role of electrotonic modulation of propagation. J Cardiovasc Electrophysiol 1996;7:843-861.

25. Meijler FL, Wittkampf FHM: Role of the atrioventricular node in atrial fibrillation. In Falk RH, Podrid PJ, eds: Atrial Fibrillation: Mechanisms and Management. Second Edition. Lippincott-Raven Publishers, Philadelphia, 1997, pp. 109-131.

26. van Wezel-Meijler G, van Genderingen HR, Meijler FL: Atrioventriculaire geleiding bij te vroeg geborenen ongeveer de helft van die bij volwassenen. (Atrioventricular conduction time in premature infants about half that in adults; with English abstract) Ned Tijdschr Geneeskd 1997;141:244-247.

27. James TN: Structure and function of the AV junction. Jpn Circ J 1983;47:1-47.

28. Jack JJB, Noble D, Tsien RW: Electric Current Flow in Excitable Cells. Clarendon Press, Oxford, 1975, pp. 292-296.

29. De Mello WC: Passive electrical properties of the atrioventricular node. Pflügers Arch 1977;371:135-139.

30. Lev M, Thaemert JC: The conduction system of the mouse heart. Acta Anat 1973;85:342-352.

31. Thompson D'A: On Growth and Form. Second Edition. Cambridge University Press, Cambridge, 1963, p. 154.

32. Dagget WM, Bianco JA, Powell WJ, et al: Relative contribution of the atrial systole: Ventricular systole interval and of patterns of ventricular activation to ventricular function during electrical pacing of the dog heart. Circ Res 1970;27:69-79.

33. Jalife J, Moe GK: Excitation, conduction, and reflection of impulses in isolated bovine and canine cardiac Purkinje fibres. Circ Res 1981;49:233-247. 